\title{
Nutritional status of school age girls working in different handicraft centres of Srinagar City
}

\author{
Veena Raina, V K Bhan, N A Bhat
}

Children are employed in different industries throughout the world. In Kashmir they work mostly in proliferating handicraft centres in both the public and private sectors such as carpet weaving, shawl making, wood carving, and embroidery. They are compelled to work in unhygienic conditions in propped up squatting positions for a nominal stipend, thus tempting young school age girls to join these centres at the cost of their education because of poverty, ignorance, illiteracy of parents, and less social desire for female education. Exploitation of young girls as manual workers, a common feature in this part of the country, makes them vulnerable to ill health because of increased demands of food, nutrition, and exercise. They are subject to great stresses and strains because of long working hours, unhealthy working environment, lack of health care facilities, and faulty postures that affect their growth and development whereas girls attending school enjoy all facilities, including recreational and medical. Many studies of ill health and nutritional status of schoolchildren are available but there is practically none on the nutritional status of working school age girls, especially from this part of the country.

\section{Material and methods}

The present study was based on 1540 girls drawn randomly from 77 handicraft centres of Srinagar City from October to December 1988 with a control of 200 schoolgirls from eight zones of the city drawn randomly. Full dietary history on a proforma was collected from both groups, including daily food consumption.

Anthropometric measurements of weight, height, and mid-arm circumference were recorded by standard recommended methods.

(a) Weight: using a platform beam balance and recording to the nearest $0 \cdot 1 \mathrm{~kg}$.

(b) Height: recorded to the nearest $0.1 \mathrm{~cm}$ after removing shoes and standing in an upright position parallel to the wall.

(c) Mid-arm circumference: This was measured in the left upper arm while hanging freely at

Sher-i-Kashmir Institute of Medical Sciences, Soura Srinagar, Kashmir

V Raina, V K Bhan, N A Bhat its mid-point between the acromial and olecranon processes, gently avoiding compression of the soft tissues.

Haemoglobin concentration was measured by Sahli's method wherever indicated and when the child cooperated.

\section{Results}

The mean age of handicraft workers was 12.7 years $\vec{c}$ $(\mathrm{SD} \pm 2.45)$ compared with 11.6 years $(\mathrm{SD} \pm 3.26)$ in the schoolgirls. Most parents of working girls were unemployed $(28.57 \%)$, labourers $(20.0 \%)$, and small shopkeepers $(8.0 \%)$; in the control group the fathers were government servants $(32.0 \%)$ or successful business men $(25.0 \%)$, having a better socioeconomic status with literacy levels of $53.0 \%$ of fathers of schoolgirls against $16.6 \%$ in the handicraft workers group. Immunisation status did not show any sig- $\mathbb{\mathbb { D }}$ nificant difference. Average height increased from 107.20 to $152.75 \mathrm{~cm}$ in schoolgirls whereas in handicraft workers it increased from 105.50 to $150.40 \mathrm{~cm}$ from age 6 to 16 (table 1). A regular increase in height appeared up to 12 years in both

Table 1 Average height $(\mathrm{cm})$

\begin{tabular}{|c|c|c|}
\hline Age (y) & $\begin{array}{l}\text { Handicraft workers } \\
(\text { Mean } \pm S D)\end{array}$ & $\begin{array}{l}\text { Schoolgirls } \\
(\text { Mean } \pm S D)\end{array}$ \\
\hline $\begin{array}{l}6 \\
7 \\
8 \\
9 \\
10 \\
11 \\
12 \\
13 \\
14 \\
15 \\
16\end{array}$ & $\begin{array}{l}105.50 \pm 0.976 \\
110.00 \pm 2.00 \\
115.70 \pm 6.45 \\
121.00 \pm 5.09 \\
128.00 \pm 5.71 \\
132.30 \pm 3.64 \\
136.85 \pm 4.61 \\
143.51 \pm 4.08 \\
145.14 \pm 5.11 \\
147.50 \pm 5.61 \\
150.40 \pm 4.97\end{array}$ & $\begin{array}{l}107.20 \pm 2.96 \\
111.60 \pm 1.87 \\
119.80 \pm 2.76 \\
123.55 \pm 2.81 \\
129.80 \pm 1.67 \\
134.67 \pm 3.01 \\
138.85 \pm 3.11 \\
147.52 \pm 3.97 \\
148.10 \pm 2.61 \\
148.83 \pm 4.01 \\
152.75 \pm 4.13\end{array}$ \\
\hline
\end{tabular}

Analysis of variance

\begin{tabular}{llllrl}
\hline Source of & $\begin{array}{l}\text { Differ- } \\
\text { ence } \\
\text { (df) }\end{array}$ & $\begin{array}{l}\text { Sum of } \\
\text { square } \\
\text { (SS) }\end{array}$ & $\begin{array}{l}\text { Mean sum } \\
\text { of square } \\
\text { (MSS) }\end{array}$ & F Value & p Value \\
\hline Due to age & 10 & 4958.7 & 495.871 & 475.42 & $<0.005^{\star}$ \\
Due to group & 1 & 30.65 & 30.65 & 29.40 & $<0.005^{\star}$ \\
Error & 10 & 10.43 & 1.043 & & \\
Total & 21 & 4999.93 & & & \\
\hline
\end{tabular}

^Highly significant result. 
Table 2 Average weight ( $\mathrm{kg}$ )

\begin{tabular}{lll}
\hline Age $(y)$ & $\begin{array}{l}\text { Handicraft workers } \\
(\text { Mean } \pm S D)\end{array}$ & $\begin{array}{l}\text { Schoolgirls } \\
\text { (Mean } \pm S D)\end{array}$ \\
\hline 6 & $15.35 \pm 0.90$ & $16.55 \pm 0.81$ \\
7 & $16.40 \pm 1.94$ & $18.20 \pm 1.71$ \\
8 & $18.78 \pm 2.91$ & $20.00 \pm 2.01$ \\
9 & $20.71 \pm 3.24$ & $21.23 \pm 2.74$ \\
10 & $22.70 \pm 3.49$ & $23.36 \pm 2.91$ \\
11 & $26.35 \pm 4.81$ & $27.95 \pm 2.97$ \\
12 & $32.77 \pm 4.24$ & $33.04 \pm 3.81$ \\
13 & $32.81 \pm 5.31$ & $33.20 \pm 4.81$ \\
14 & $37.86 \pm 5.21$ & $38.55 \pm 4.91$ \\
15 & $39.20 \pm 4.37$ & $39.58 \pm 3.89$ \\
16 & $42.61 \pm 4.51$ & $43.66 \pm 4.73$ \\
\hline
\end{tabular}

Analysis of variance

\begin{tabular}{lrrrrr}
\hline $\begin{array}{l}\text { Source of } \\
\text { variance }\end{array}$ & $d f$ & $S S$ & $\begin{array}{l}\text { MS of } \\
\text { score }\end{array}$ & F value & p value \\
\hline Due to age & 10 & 1837.20 & 183.72 & 394.67 & $<0.05^{\star}$ \\
Due to group & 1 & 5.98 & 5.98 & 9.91 & $<0.025^{\star \star}$ \\
Error & 10 & 6.03 & 0.603 & & \\
Total & 21 & 1849.21 & & & \\
\hline
\end{tabular}

$\star$ Significant difference.

$\star \star$ Highly significant difference.

groups and thereafter slight fluctuations were observed. The analysis of variance test exhibits highly significant differences in height estimates at $\mathrm{p}<0.005$, thereby inferring that schoolgirls have comparatively better physical growth than handicraft workers.

Comparison of the average weight in the two groups and assessment by analysis of variance test (table 2) indicated positive responses in the weight estimates, with a steady rise in weight up to age 12 . After that some irregular increasing tendency was observed in both groups but at all ages schoolgirls appeared to be heavier than handicraft workers. The weight increase in handicraft workers was from 15.35 to $42.61 \mathrm{~kg}$, whereas in schoolgirls the increase was from 16.55 to $43.66 \mathrm{~kg}$. The statistical test applied for changes in weight from age to age and to assess the significance suggested that schoolgirls were heavier than handicraft workers. Analysis of variance test showed highly significant differences between the two groups ( $p<0.025)$ (table 2 ). Mid-arm circumference estimated in the two groups indicated overall increasing tendency in both the groups with advancing age. Among handicraft workers it fluctuated between $15.48-20.07 \mathrm{~cm}$ against $15.68-20.41 \mathrm{~cm}$ in the schoolgirls. In between ages the mid-arm circumference does not follow systemic increase tendencies such as the height and weight estimates. Despite an irregular rise in mid-arm, the length assessed among schoolgirls appeared to be better than the handicraft workers with a highly significant difference $(p<0.01)$ displayed on application of the analysis of variance test.

The evaluation of nutritional defects showed a higher percentage of nutritional defects such as pale conjuctiva, angular stomatitis, and dermatitis (rough skin) in handicraft workers than in the schoolgirls. Dental caries, however, was observed in $8 \%$ of the schoolgirls and $2.29 \%$ of handicraft workers (table 3).

Distribution of children by level of haemoglobin in the two groups showed that haemoglobin level varied from 7.5 to $14 \mathrm{~g} / \mathrm{dl}$ among handicraft workers with an average level of $11.33 \pm 1.40 \mathrm{~g} / \mathrm{dl}$ compared with 8$14 \mathrm{~g} / \mathrm{dl}$ with average level of $11.93 \pm 9.9 \mathrm{~g} / \mathrm{dl}$ among the schoolgirls. The difference in the levels of haemoglobin between the two groups was highly significant $(\mathrm{p}<0.01)$.

\section{Discussion}

Poverty is an important factor that is responsible for child employment besides a cultural trend that is consistent with findings on carpet weaving centres. To outstrip child employment overall socioeconomic transformation seems to be imperative.

Table 3 Clinical nutrition examination

\begin{tabular}{|c|c|c|c|c|}
\hline \multirow[b]{2}{*}{ Nutritional defect } & \multicolumn{2}{|c|}{ Handicraft workers } & \multicolumn{2}{|c|}{ Schoolgirls } \\
\hline & $(\mathrm{No})$ & $(\%)$ & (No) & $(\%)$ \\
\hline $\begin{array}{l}\text { Normal } \\
\text { None }\end{array}$ & 269 & $76 \cdot 86$ & 165 & $82 \cdot 5$ \\
\hline $\begin{array}{l}\text { Nutritional defect } \\
\text { Hair: lack of lustre } \\
\text { Eyes: pale conjuctiva } \\
\text { Lips: angular stomatitis } \\
\text { Tongue: scarlet } \\
\text { Atrophic papillae } \\
\text { Skin: rough dry } \\
\text { Gums: spongy bleeding } \\
\text { Teeth: mottled enamel } \\
\text { Caries }\end{array}$ & $\begin{array}{r}4 \\
18 \\
17 \\
8 \\
5 \\
5 \\
15 \\
11 \\
8 \\
8\end{array}$ & $\begin{array}{l}1 \cdot 14 \\
5 \cdot 14 \\
4 \cdot 86 \\
2 \cdot 29 \\
1 \cdot 43 \\
4 \cdot 29 \\
3 \cdot 14 \\
2 \cdot 29 \\
2 \cdot 29\end{array}$ & $\begin{array}{r}2 \\
5 \\
4 \\
2 \\
4 \\
4 \\
7 \\
3 \\
16\end{array}$ & $\begin{array}{l}1 \cdot 0 \\
2 \cdot 5 \\
1 \cdot 142 \\
1 \cdot 0 \\
1 \cdot 142 \\
1 \cdot 112 \\
3 \cdot 5 \\
1 \cdot 5 \\
8 \cdot 0\end{array}$ \\
\hline $\begin{array}{l}\text { Total nutrition deficient } \\
\text { Proportion of nutrition deficient signs } \\
\text { Proportional difference }\end{array}$ & $\begin{array}{l}81 \\
0.231 \\
\text { Insigni }\end{array}$ & $23 \cdot 14$ & $\begin{array}{l}35 \\
0.175\end{array}$ & $17 \cdot 5$ \\
\hline
\end{tabular}


Anthropometric measurements of height, weight (tables 1 and 2), and mid-arm circumference in the two groups showed differences statistically significant at varying probability levels. Mattoo ${ }^{1}$ also reported better anthropometric measurements among schoolchildren than carpet weavers of the same age, attributing this to poor socioeconomic status, undernourishment, and physical strain. Regular rises up to age 12 in height, weight, and midarm circumference in both groups and fluctuation at a later age were comparable with the observations of Levin in a study of labour in Japan. ${ }^{2}$ He observed that the height and weight of girls employed in factories and pupils were almost the same up to age 12 but later physical development among girls was definitely affected by physical work and differences among them increased each year. So physical work among handicraft workers seems to be responsible for retardation of growth.

Clinical examination of nutrition showed an overall higher percentage of nutritional defects in handicraft workers than schoolgirls but dental caries was higher in schoolchildren owing to their consuming sweets usually sold by vendors at school gates and not cleaning their teeth immediately. Overall, better $\stackrel{\mathbb{P}}{?}$ nutritional status among schoolgirls is due to better $\overrightarrow{\vec{B}}$ socioeconomic status.

Haemoglobin estimates were again better in $\bar{c}$ schoolgirls than handicraft workers $(p<0.01)$ in agreement with observations of Mattoo. ${ }^{1}$

Recreational facilities were present in only three $\stackrel{\mathbb{Q}}{\AA}$ handicraft centres but were in all schools. No basic $\nRightarrow$ medical facilities or midday meals were seen among $\vec{\circ}$ handicraft workers, although they existed in schools. The Labour Bureau made similar observations. ${ }^{3}$

Employment of young girls in handicraft centres is detrimental to their growth and development. To avoid exploitation of child labour, compulsory education and strict legislative measures are desirable.

1 Mattoo GM. A study of health status in school age girls employed in 윽 carpet weaving in Ganderbal Block of Kashmir. India: University of Kashmir, 1982. (MD thesis.)

2 Levin L. Too young to work. World Health 1984:24-27.

3 Labour Bureau. Report on survey of labour conditions on metal rolling/silk factories in India. Ministry of Labour and Employment, 1959.

Accepted 2 October 1989 